\title{
New Approach of Incremental Conductance Algorithm for Maximum Power Point Tracking Based on Fuzzy Logic
}

\author{
Hichem OTHMANI*, Dhafer MEZGHANI, \\ Ahmed BELAID and Abdelkader MAMI \\ University of Tunis El Manar, Faculty of Sciences of Tunis, Department of \\ Physics, The university Campus of Farhat Hached B.P. $n^{\circ} 94$ - Rommana 1068 \\ Tunis, Tunisia, \\ *hichem.othmani.fst.rnu@gmail.com;
}

\begin{abstract}
Tracking the maximum power point is an appropriate solution against climatic changes like the irradiance and temperature. The classic incremental conductance algorithm is one of the most widely used methods in commercial photovoltaic MPPT's (Maximum Power Point Tracking). A wide variation of climatic condition can degrade the produced energy. In this work we present our new approach based on fuzzy logic which can guarantee better performance. The studied system used to prove the efficiency of the proposed method is composed by a photovoltaic panel Kaneka K60 connected to a Sepic Converter which fed a resistive load. The All results quoted in this work are found using MATLAB-Simulink. We put the system in different working condition to highlight our new approach. All presented results are discussed.
\end{abstract}

Keywords: Photovoltaic Panel, Sepic converter, MPPT, Incremental conductance algorithm, fuzzy logic.

\section{Introduction}

The request on electric energy is increasing in recent years and the constraints related to its production, such as the pollution effect and global warming, lead research towards the development of renewable energy sources. In this context, photovoltaic (PV) systems offer a very compeis titive solution. To overcome the problems related to solar panels (such as adaptation) and get a maximum energy, it is necessary to optimize the design of all parts of the PV system. Furthermore, it is necessary to optimize the converters (DCDC). This converter is used as an interface between PV generator and the load in order to extract maximum power and thus making the generator on its maximum power point (MPP). The DC-DC converter is controlled by an MPPT algorithm (maximum power point tracking) [1] [2]. Maximum power point tracking is a mechanism which can guarantee the maximal power permanently [3]. Several method of MPPT have been proposed in the literature, such as the Perturb and Observe algorithms [4] [5] [6], and incremental conductance algorithms [7] [8]. The Classical incremental conductance algorithms are based on the instantaneous incremental conductance to find the maximum power point [9] [10]. The main advantage of this algorithm is that it provides a good performance under changing climatic conditions. But a small increment value slows the search of the maximum power point. We must find a compromise between accuracy and speed, what makes this algorithm difficult to optimize. This work presents a new approach for incremental conductance method based on fuzzy logic in order to obtain better performances against climatic conditions change. First, we will present the model of the photovoltaic panel. Next, we will give the principle of operation of the Sepic

${ }^{1}$ Hichem Othmani is the corresponding author. 
converter used in this work. Then we will introduce the classical and the new method for tracking the maximum power point. We will finish by giving simulation results to illustrate the efficiency of the proposed method.

\begin{tabular}{|c|c|}
\hline \multicolumn{2}{|l|}{ Nomenclature } \\
\hline PV & Photovoltaic system \\
\hline MPPT & Maximum Power Point Tracking \\
\hline $\mathrm{I}_{\mathrm{pv}}$ & Output current of the solar generator \\
\hline $\mathrm{V}_{\mathrm{pv}}$ & Voltage of the solar generator \\
\hline $\mathrm{I}_{\mathrm{ph}}$ & Photovoltaic generator photocurrent, \\
\hline $\mathrm{I}_{\mathrm{s}}$ & Photovoltaic cell reverse saturation current diode $1.502410^{-2} \mathrm{~A}$ \\
\hline $\mathrm{I}_{\mathrm{cc}}$ & Short Circuit current \\
\hline $\mathrm{K}$ & Botzman Constant $1.3910^{-23} \mathrm{~m}^{2} \mathrm{~kg} \mathrm{~s}^{-2} \mathrm{~K}^{-1}$ \\
\hline $\mathrm{Eg}$ & Gap energy $1.7910^{-19} \mathrm{~J}$ \\
\hline $\mathrm{n}$ & ideality factor 630.97 \\
\hline $\mathrm{Ki}$ & Temperature coefficient in current \\
\hline G & Irradiance \\
\hline $\mathrm{T}, \mathrm{T}_{\text {ref }}$ & Temperature and reference temperature $25^{\circ} \mathrm{C}$ \\
\hline $\mathrm{T}_{\mathrm{p}}$ & Junction temperature \\
\hline $\mathrm{R}_{\mathrm{s}}$ and $\mathrm{R}_{\mathrm{p}}$ & the series and shunt resistance respectively, \\
\hline G & the irradiance, \\
\hline $\mathrm{C}$ & the number of cells (in series) per module, \\
\hline $\mathrm{V}_{\mathrm{oc}}$ & the open circuit voltage of the module, \\
\hline q & the elementary charge in Coulomb. \\
\hline $\mathrm{V}_{\mathrm{IN}}$ & the input voltage of the Sepic convertre \\
\hline $\mathrm{V}_{\text {OUT }}$ & the output voltage of the Sepic converter \\
\hline $\mathrm{I}_{\mathrm{IN}}$ & the input current of the Sepic converter \\
\hline $\mathrm{I}_{\text {OUT }}$ & the output current of the Sepic converter \\
\hline $\mathrm{I}_{\mathrm{L}}$ & the current in the coil of the Sepic converter \\
\hline$V_{D}$ & the threshold voltage of the diode of the Sepic converter \\
\hline$f_{S W}$ & the switching frequency \\
\hline $\mathrm{C}_{\mathrm{s}}$ & value of the coupling capacitor of the Sepic converter \\
\hline $\mathrm{C}_{\text {in }}$ & value of the input capacitor of the Sepic converter \\
\hline $\mathrm{C}_{\text {out }}$ & value of the output capacitor of the Sepic converter \\
\hline $\mathrm{V}_{\mathrm{Cs}}$ & the voltage of the coupling capacitor \\
\hline D & the duty cycle \\
\hline$D_{\max }$ & the maximal duty cycle \\
\hline$V_{t}$ & the thermodynamic voltage \\
\hline $\mathrm{I}_{\mathrm{mpp}}$ & Nominal current at maximum power point \\
\hline $\mathrm{V}_{\mathrm{mpp}}$ & Nominal voltage at maximum power point \\
\hline $\mathrm{P}_{\mathrm{mpp}}$ & Nominal power at maximum power point \\
\hline
\end{tabular}

\section{Photovoltaic Panel Modeling}

The conversion of solar radiation into electricity by the photovoltaic process is one of the exploitation means of solar potential. A photovoltaic panel is mathematically modeled by the following equations [11]:

$$
\begin{aligned}
& I_{p v}=I_{p h}-I_{d}-I_{s h} \\
& I_{d}=I_{s}\left(\exp \left(\frac{\left(V_{p v}+R_{s} I_{p v}\right)}{n C V_{t}}\right)-1\right)
\end{aligned}
$$




$$
\begin{aligned}
& I_{s h}=\left(\frac{V_{p v}+R_{s} \cdot I_{p v}}{R_{p}}\right) \\
& I_{p h}=G\left(I_{s c}+K_{i}\left(T-T_{r e f}\right)\right) \\
& I_{s}=I_{r s}\left(T-T_{r e f}\right) \exp \left(\frac{E_{g \cdot} \cdot q^{2}}{K \cdot n}\left(\frac{1}{T}-\frac{1}{T_{r e f}}\right)\right) \\
& \left.I_{r s}=\frac{I_{s c}}{q \cdot V_{o c}}\right) \\
& V_{t}=\frac{\exp \left(\frac{K \cdot K C T}{q}\right.}{n \cdot K C T}
\end{aligned}
$$

$R_{s}$ and $R_{p}$ are the series and shunt resistors respectively, $T_{\text {ref }}$ is the ambient temperature token as reference, $\mathrm{G}$ is the irradiance, $\mathrm{n}$ is the ideality factor of the diode, $\mathrm{T}$ is the temperature cell, $\mathrm{K}$ is the Boltzmann constant, $\mathrm{E}_{\mathrm{g}}$ is the gap energy, $\mathrm{C}$ is the number of cells (in series) per module, $\mathrm{V}_{\mathrm{oc}}$ is the open circuit voltage of the module, $\mathrm{I}_{\mathrm{sc}}$ is the short circuit current of the module, $\mathrm{K}_{\mathrm{i}}$ is the coefficient of temperature and $\mathrm{q}$ is the elementary charge in Coulomb. The change of irradiance and temperature directly influences the power produced by the panel the following figures illustrate this effect.

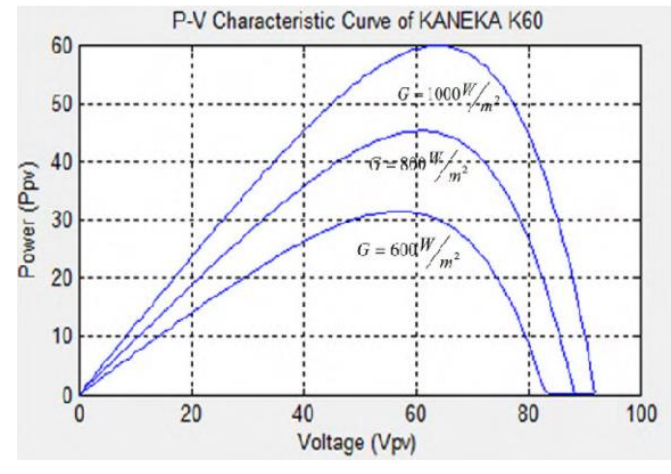

Temperature are fixed at $25^{\circ} \mathrm{C}$

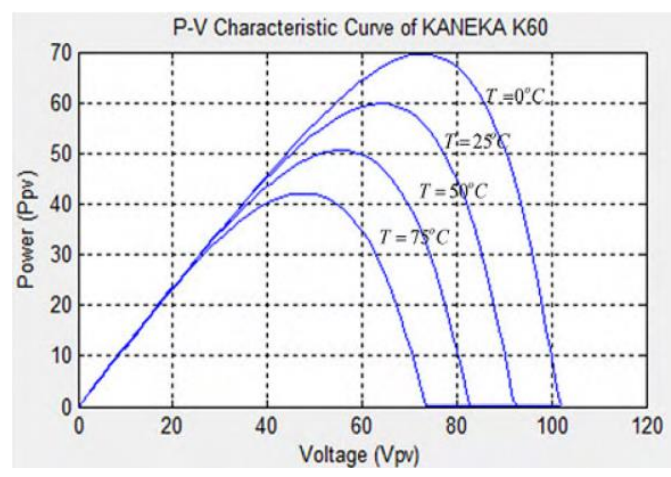

Irradiance are fixed at $1000 \mathrm{w} / \mathrm{m}^{2}$

\section{Figure 1. The Irradiance and Temperature Effect on the Power Produced by the Kaneka K60}

The photovoltaic panel used in this work is Kaneka K60 module. The electrical parameters of this module are shown in Table1:

Table 1. Characteristics of the Kaneka K60 at Optimal Conditions

\begin{tabular}{|c|c|}
\hline Parameters & Value \\
\hline Nominal Power & $60 \mathrm{w}(+10 \% /-5 \%)$ \\
\hline Voltage at maximum power & $67 \mathrm{~V}$ \\
\hline Current at maximum power & $0.9 \mathrm{~A}$ \\
\hline Open circuit voltage & $92 \mathrm{~V}$ \\
\hline Short circuit current & $1.19 \mathrm{~A}$ \\
\hline
\end{tabular}




\section{Sepic Converter}

To obtain maximum energy for any weather condition, we should take care of the load's impedance. In buck operation this impedance should be as near as possible and less than $\mathrm{R}_{\mathrm{opt}}\left(\mathrm{R}_{\mathrm{opt}}=\mathrm{V}_{\mathrm{mpp}} / \mathrm{I}_{\mathrm{mpp}}\right), \mathrm{V}_{\mathrm{mpp}}$ and $\mathrm{I}_{\mathrm{mpp}}$ are respectively the voltage and current at maximum power point). In boost operation this impedance should be as near as possible as and larger than $\mathrm{R}_{\mathrm{opt}}$.

Sepic converter is one of the converters which are able to ensure optimal operation regardless of the load [12].

Sepic converter has many advantages:

- It can function as buck-boost converter without polarity reversal.

- $\quad$ The control of the transistor refers to the electrical ground.

- The ripple of the input current is limited.

- $\quad$ A good yield.

The SEPIC converter was designed in the late 1970s by Slobodan Cuk. The structure of SEPIC is deduced from that of capacitive Cuk by permuting the diode and the output inductor. It has similar features to the Cuk, but the input voltage is not inverted. The output voltage can be higher or lower than the input voltage. The SEPIC converter has two coils L1 and L2. The output voltage depends on the duty cycle applied to the switch K [13].

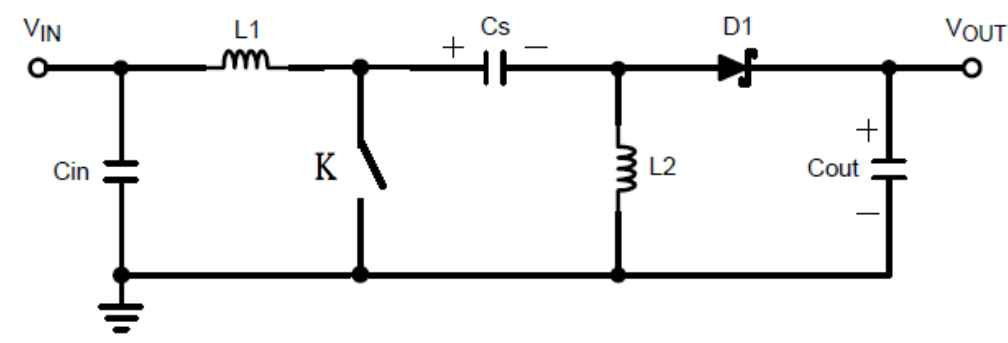

Figure 2. Sepic Converter Topology

When the duty cycle reached $50 \%$, the input voltage will be equal to the output voltage. When higher, the output voltage will be lower than input voltage. And finally the output voltage will exceed the input voltage if lower. If we apply the Kirchhoff's voltage law the duty cycle will be given by [14]:

$$
D=\frac{V_{\text {OUT }}+V_{D}}{V_{\text {IN }}+V_{\text {OUT }}+V_{D}}
$$

With $\mathrm{V}_{\text {IN }}$ is the input voltage, $\mathrm{V}_{\text {OUT }}$ is the output voltage and $\mathrm{V}_{\mathrm{D}}$ is the threshold voltage of the diode. For the desired output, the variation of the duty cycle will depend on the input voltage. Thus, the maximum duty cycle is [14]:

$$
D_{\text {MAX }}=\frac{V_{\text {OUT }}+V_{D}}{V_{I N}(\min )+V_{\text {OUT }}+V_{D}}
$$

To find the adequate value of the coil, we must fix the maximal accepted value of ripple. We have fixed empirically that a ripple of $40 \%$ of the maximum input current for the minimum input voltage is acceptable. The current ripple is defined by the following equation [14]: 
$\Delta I_{L}=I_{I N} \times 40 \%=I_{\text {OUT }} \times \frac{V_{\text {OUT }}}{V_{I N(\min )}} \times 40 \%$

Thus, the values of inductances are calculated by: ( $f_{s w}$ is the switching frequency)

$L 1=L 2=L=\frac{V_{I N(\min )}}{\Delta I_{L} \times f_{S W}} \times D_{\max }$

The value of the coupling capacitor is defined by [14]:

$C s=\frac{I_{\text {OUT }} \times D_{\max }}{\Delta V_{C s} \times f_{S W}}$

To reduce the ripple at the input and the output, filter capacitors are used. We can remove $\mathrm{C}_{\text {in }}$ if there is no ripple in photovoltaic panel. $\mathrm{C}_{\text {out }}$ is dimensioned by [14]:

Cout $\geq \frac{I_{\text {OUT }} \times D}{V_{\text {ripple }} \times 0.5 \times f_{S W}}$

$\mathrm{I}_{\mathrm{OUT}}$ is the current in the load, $\mathrm{V}_{\text {ripple }}$ is the voltage ripple.

\section{Maximum Power Point Tracking Methods}

The MPPT (Maximum Power Point Tracking) is a control law that provides an instantaneous adaptation of the operating point of the load at maximum power provided by the Photovoltaic generator. This can be achieved through the Sepic converter inserted between the generator and the load which is dynamically controlled by varying the value of duty cycle.

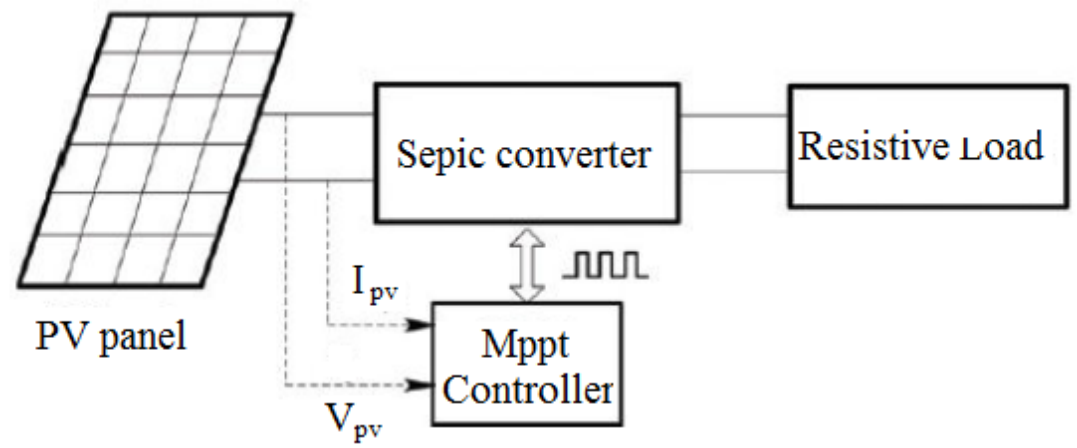

Figure 3. Synoptic of the Studied System

\subsection{Classic Incremental Conductance Algorithm [15].}

In this technique the term $\frac{d I p v}{d V p v}$ is compared to $-\frac{I p v}{V p v}$. The maximum power point is achieved when this difference is null.

$$
\begin{aligned}
& \frac{d P_{p v}}{d V_{p v}}=I_{p v} \frac{d V_{p v}}{d V_{p v}}+V_{p v} \frac{d I_{p v}}{d V_{p v}}=I_{p v}+V_{p v} \frac{d I_{p v}}{d V_{p v}}=0 \\
& -\frac{I_{p v}}{V_{p v}}=\frac{d I_{p v}}{d V_{p v}}
\end{aligned}
$$


$\mathrm{dV}_{\mathrm{Pv}_{\mathrm{v}}}$ and $\mathrm{dI}_{\mathrm{Pv}_{\mathrm{v}}}$ can be approximated by :

$$
\begin{aligned}
& d V_{p v}(k) \approx \Delta V_{p v}(k-1)=V_{p v}(k)-V_{p v}(k-1) \\
& d I_{p v}(k) \approx \Delta I_{p v}(k-1)=I_{p v}(k)-I_{p v}(k-1)
\end{aligned}
$$

In results, to review the operation of the photovoltaic panel and the power at the load we use inequalities:

$$
\begin{array}{lll}
\frac{d P_{p v}}{d V_{p v}}>0 & \text { For } & V_{p v}<V_{m p p} \\
\frac{d P_{p v}}{d V_{p v}}=0 & \text { For } & V_{p v}=V_{m p p} \\
\frac{d P_{p v}}{d V_{p v}}<0 & \text { For } & V_{p v}>V_{m p p}
\end{array}
$$

This approach is easy to implement on programmable circuit such as microcontrollers. The organization chart presented on figure 4 resume the principle of the incremental conductance algorithm.

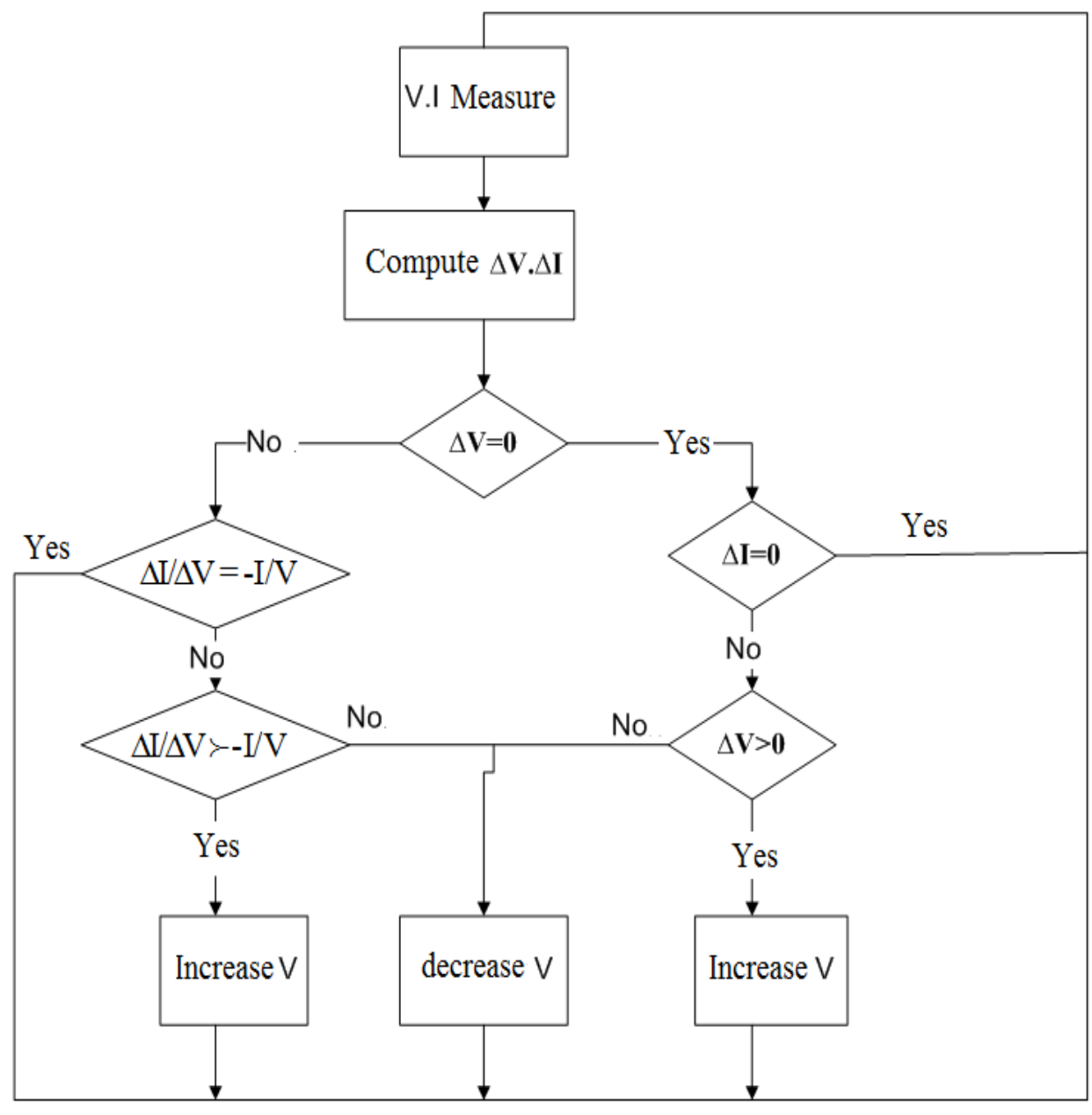

Figure 4. Diagram of Classical Incremental Conductance Algorithm 


\subsection{Proposed Method using Fuzzy Logic}

Recently, the fuzzy logic control is used for maximum point tracking. This control offers the advantage of being robust. The design of a fuzzy controller requires three stages, which are: fuzzification, inference rules and defuzzification [16].

The preliminary step, which are the fuzzification, consist on defining the maximum range of variation allowed for the input variables. The purpose of the fuzzification is to transform input variables into linguistic variables. The second stage( the inference rules) is a step which can make a logical relationship between inputs and output. Indeed, membership rules will set for the optimal output related to the actual inputs. Table 2 presents all inference rules which allow toobtain optimal duty cycle (in results optimal power point).

The linguistic variables (fuzzy variables) are not understandable by the external environment. The defuzzification consists on computing the numerical values are from linguistic variables.

Based on the previously equations cited in paragraph (4.1). We have :

$\frac{d\left(V_{p} * I_{p}\right)}{d V_{p}}=I_{p}+V_{p} * \frac{d I_{p}}{d V_{p}}$

What will bring us to

$$
\frac{d I_{p}}{d V_{p}}=-\frac{I_{p}}{V_{p}}
$$

This equality means that the photovoltaic panel is at its maximum power point. We exploit this equality to design our fuzzy logic controller wich its input are:

$$
\begin{aligned}
& E(k)=\frac{d I_{p}}{d V_{p}}+\frac{I_{p}}{V_{p}} \\
& d E(k)=\frac{E(k)-E(k-1)}{T_{e}}
\end{aligned}
$$

With $\mathrm{T}_{\mathrm{e}}$ is the sample Time.

The inputs of the fuzzy controller include only three fuzzy subsets: Negative $(\mathrm{N})$, Zeros $(\mathrm{Z})$ and Positive $(\mathrm{P})$. The $\mathrm{N}$ and $\mathrm{P}$ subset have a trapezoid shape. We applied the triangular shape for the $\mathrm{Z}$ subset. The choice of these shapes is empirical.

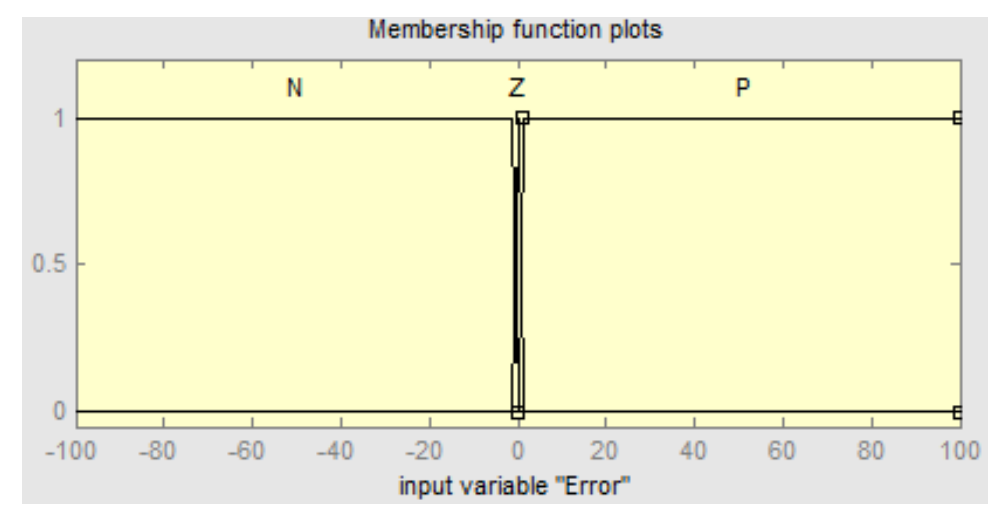

Figure 5.(a). Fuzzification Step of $E(k)$ 


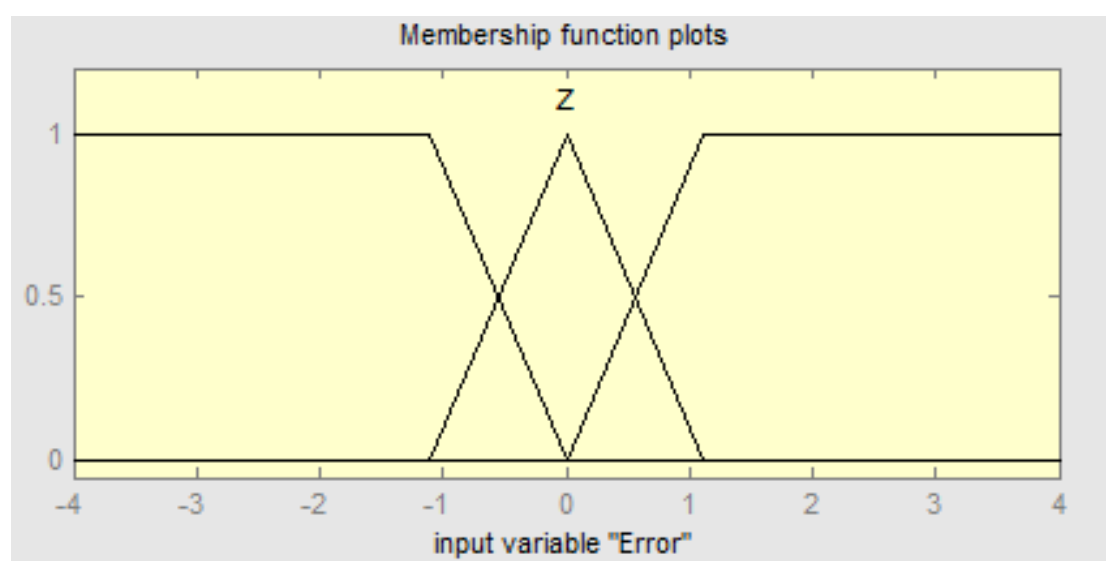

Figure 5.(b). Fuzzification Step of E(k) (Zoom In)

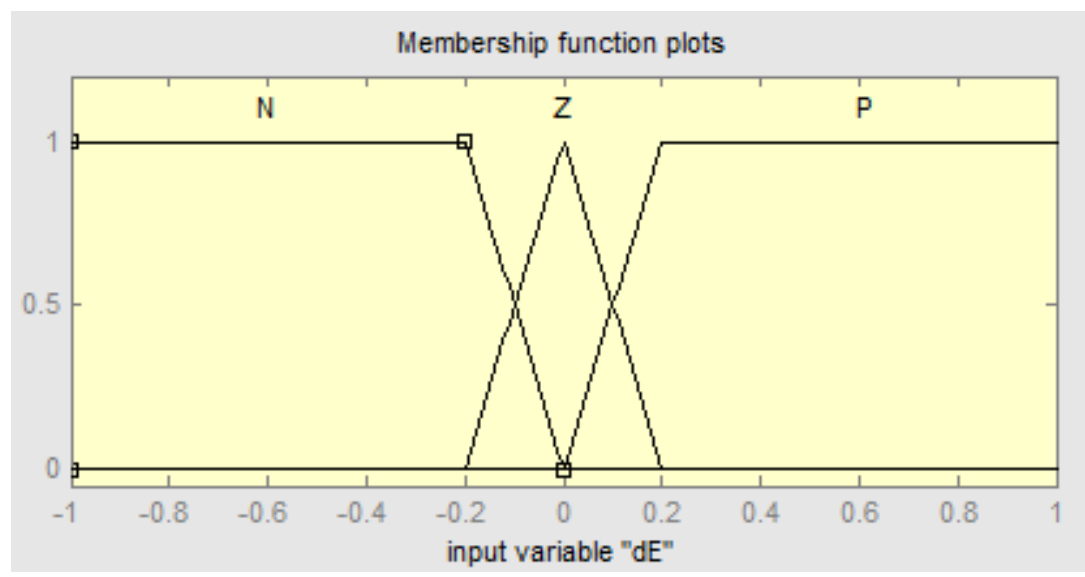

Figure 6. Fuzzification Step of $d E(k)$

Where $\mathrm{D}(\mathrm{k})$ is the output of the fuzzy controller which includes five fuzzy subsets (numbered from 1 to 5). It allows obtaining the maximum precision of the duty D which can reduce the time to achieve the maximum power point.

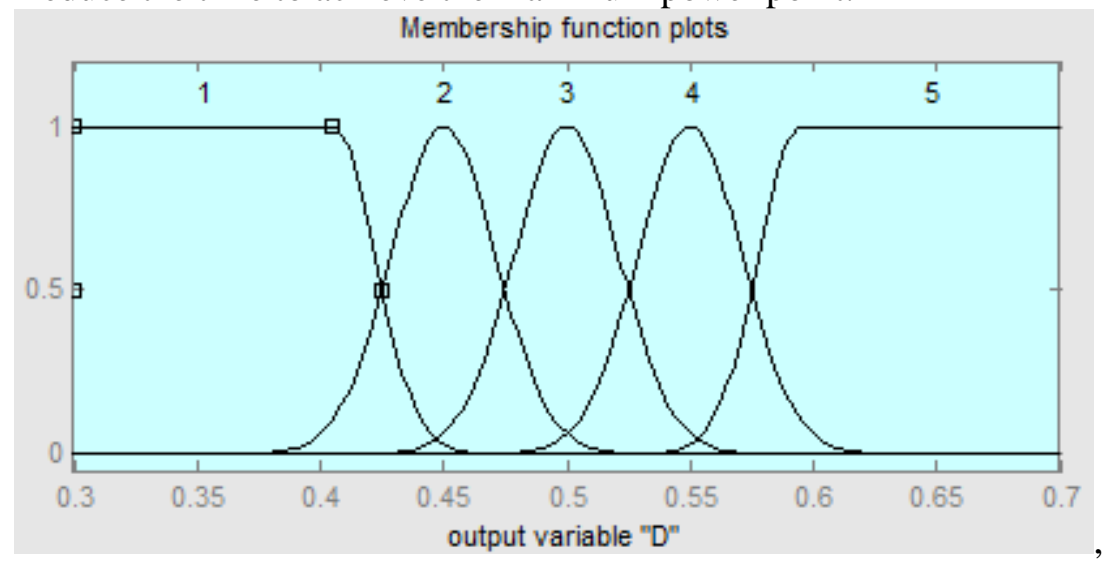

Figure 7. Defuzzification Step of $D(k)$

Related to the choice adopted for the fuzzification of input and the defuzzification of the output, there are nine inference rules on the data base of the fuzzy controller. We use Mamdani's method with Max-Min for fuzzy combination. The fuzzy controller rules are based on Table 2: 
Table 2. Basic Inference Rules for the Fuzzy Controller

\begin{tabular}{|c|c|c|c|}
\hline Rules & $\boldsymbol{E}$ & $\boldsymbol{d} \boldsymbol{E}(\boldsymbol{k})$ & $\boldsymbol{D}$ \\
\hline 1 & $\mathrm{Z}$ & $\mathrm{N}$ & 2 \\
\hline 2 & $\mathrm{Z}$ & $\mathrm{P}$ & 4 \\
\hline 3 & $\mathrm{Z}$ & $\mathrm{Z}$ & 3 \\
\hline 4 & $\mathrm{P}$ & $\mathrm{P}$ & 1 \\
\hline 5 & $\mathrm{P}$ & $\mathrm{Z}$ & 1 \\
\hline 6 & $\mathrm{P}$ & $\mathrm{N}$ & 1 \\
\hline 7 & $\mathrm{~N}$ & $\mathrm{~N}$ & 5 \\
\hline 8 & $\mathrm{~N}$ & $\mathrm{Z}$ & 5 \\
\hline 9 & $\mathrm{~N}$ & $\mathrm{P}$ & 5 \\
\hline
\end{tabular}

\section{Simulation Results and Discussion}

In order to highlights the performance of the designed controller, we have simulate the structure presented by figure 3 . In this structure, we have used the proposed controller based on fuzzy logic and the classical incremental conductance to compare its results. Both controllers are simulated with the same climatic condition variations shown on Table 3.

Table 3. Irradiance and Temperature Variation According to the Simulation Time

\begin{tabular}{|c|c|c|}
\hline $\begin{array}{c}\text { Simulation } \\
\text { time }\end{array}$ & $\boldsymbol{G ( w / \boldsymbol { m } ^ { 2 } )}$ & $\boldsymbol{T}\left({ }^{\circ} \boldsymbol{C}\right)$ \\
\hline$[0,2]$ & 800 & 25 \\
\hline$[2,4]$ & 1000 & 18 \\
\hline$[4,6]$ & 1000 & 40 \\
\hline$[6,8]$ & 800 & 18 \\
\hline$[8,10]$ & 1000 & 20 \\
\hline$[10,12]$ & 1000 & 35 \\
\hline$[12,14]$ & 900 & 20 \\
\hline
\end{tabular}

Numerical simulations shown on Figure 8 describe the power behaviors related to proposed controller based on fuzzy logic and classical incremental conductance algorithm.

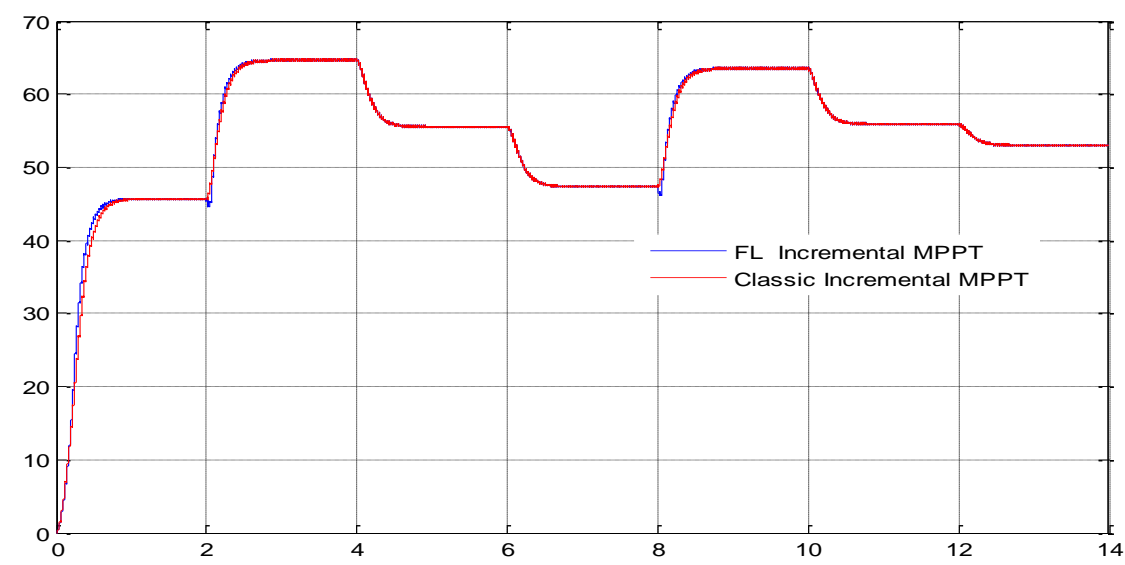

Figure 8. General Power Behaviour 
The following figures zoom the behaviour of each controller for several times.

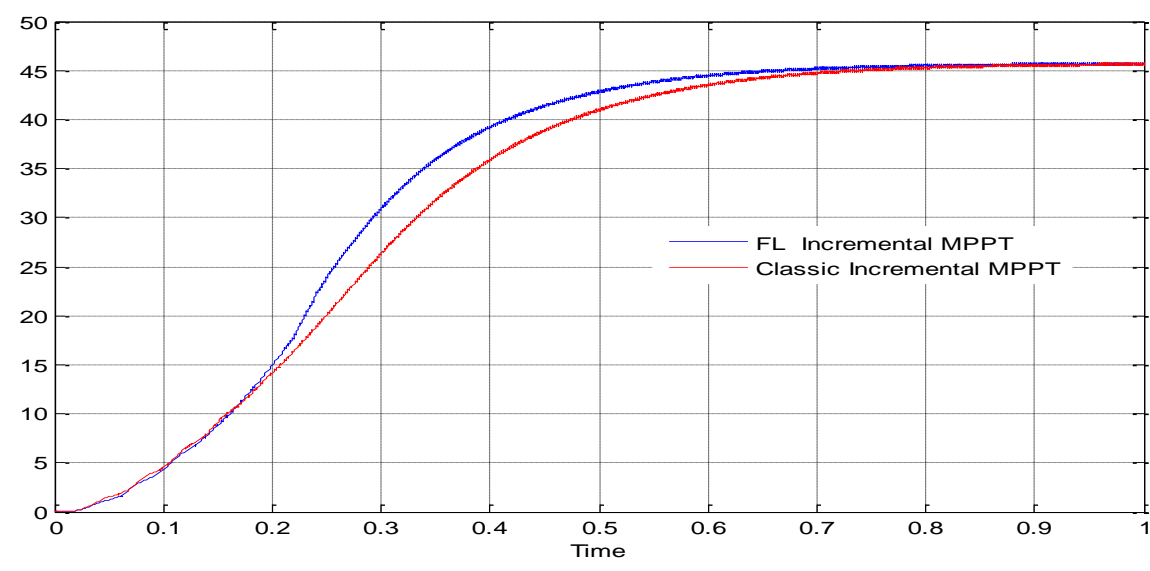

Figure 9. Power Behavior at $[0,1]$ Second of Time Simulation

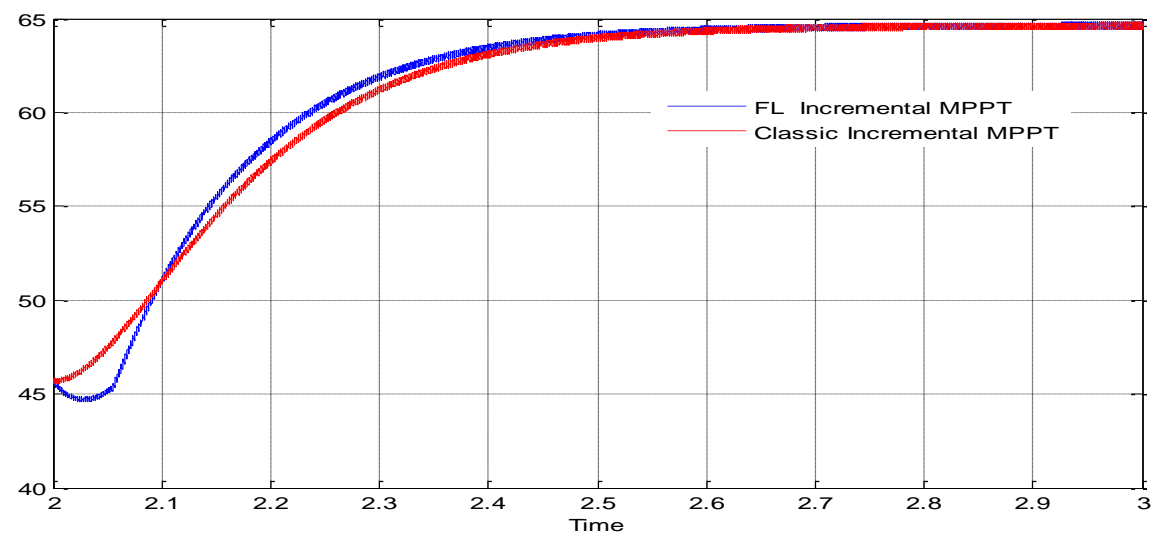

Figure 10. Power Behavior at $[2,3]$ Second of Time Simulation

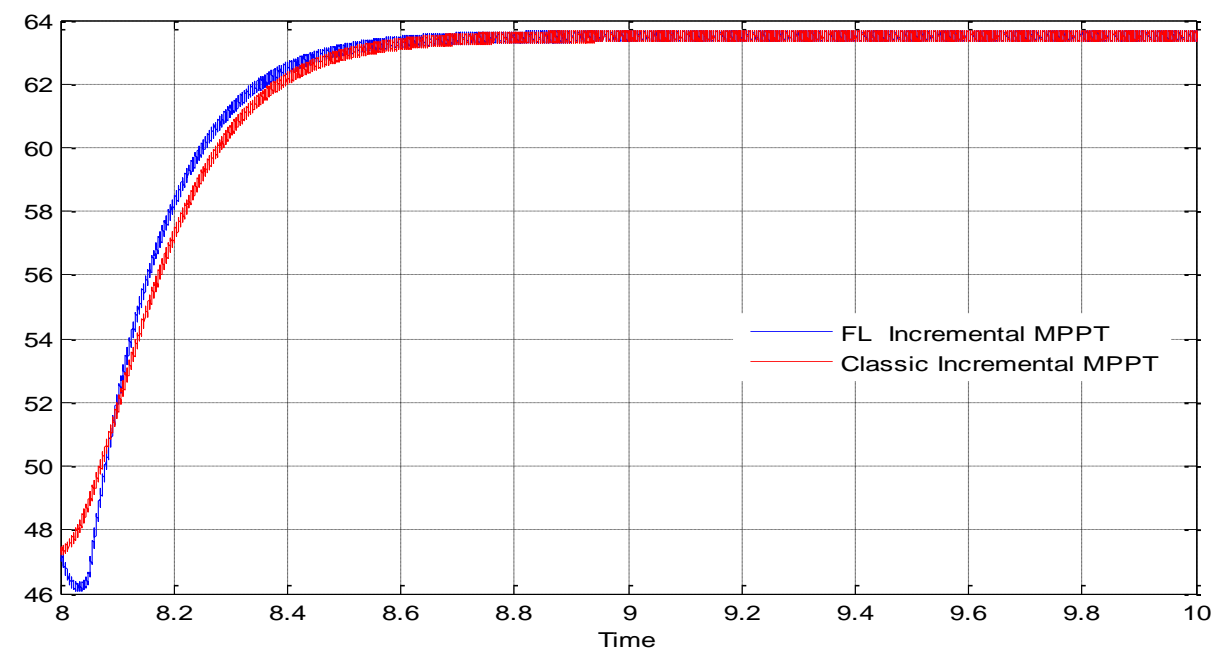

Figure 11. Power Behavior at $[8,10]$ Second of Time Simulation

Despite these disturbances, we note that the system converges to its point of maximum power and it remains stable with a near-zero ripple factor. The rise time 
about $0.5 \mathrm{~s}$ for classical MPPT control and $0.4 \mathrm{~s}$ for the proposed controller based on fuzzy logic which are both a moderate transient time.

At this level we can say that both presented algorithm provide satisfying results. But the proposed method tracks the Maximum power point more quickly than the classical method especially when there is a wide variation of climatic condition. The small divergence seen on the curve of the proposed method (at the start of each tracking caused by the variation of climatic conditions) is related on the strong correlation between membership functions. The elimination of this small divergence causes the lost of the obtained advance at the level of speed compared to classical method.

\section{Conclusion}

We presented a new incremental conductance method based on fuzzy logic. We have used a system which is composed by photovoltaic panel, Sepic converter which is controlled by the MPPT algorithm and a resistive load. The results prove that the proposed method gives better performance than the classical method.

\section{References}

[1] A.I. Bratcu, I. Munteanu, S. Bacha, D. Picault, B. Raison, "Cascaded DC-DC converter photovoltaic systems: power optimization", IEEE Trans. Ind. Electron. vol.58, (2011), pp. 403-411.

[2] S. Jain, V. Agarwal, S. Bacha, D. Picault, B. Raison, "A single-stage grid connected inverter topology for solar PV systems with maximum power point tracking”, IEEE Trans. Power Electron. vol.22, (2007), pp. $1928-1940$.

[3] M. Azab, “A New Maximum Power Point Tracking for Photovoltaic Systems", International Journal of Electrical and Electronics Engineering. vol 3: no. 11, (2009)

[4] A. K.. Abdelsalam, A.M. Massoud, S. Ahmed, P. Enjeti, "High Performance adaptive perturb and observe MPPT technique for photovoltaic-based microgrids.", IEEE Trans. Power Electron. vol.26, (2011), pp. 1010-1021.

[5] A. Zegaoui, M. Aillerie, P. Petit, J.P. Sawicki, J.P. Charles, A.W. Belarbi "Dynamic behaviour of PV generator trackers under irradiation and temperature changes", Solar Energy. vol.85, (2011), pp. 29532964.

[6] W.J.A. Teulings, J.C. Marpinard, A. Capel, D. O’Sullivan, “ A new maximum power point tracking system", Proceedings of the 24th International Congress of the Power Electronics Specialists Conference, New York, USA, (1993) June 20-24.

[7] W. Xiao, W.G. Dunford, "A modified adaptive hill climbing MPPT method for photovoltaic power systems", Proceedings of the 35th International Congress of the Power Electronics Specialists Conference, Aachen, Germany, (2004) June 20-25.

[8] Z. Xuesong, S. Daichun, M. Youjie, C. Deshu, "The simulation and design for MPPT of PV system based on incremental conductance method Proceedings of $2^{\text {nd }}$ International Conference on Information Engineering, Wuhan, China, (2010) December 25-26.

[9] A. Safari, S. Mekhilef, "Simulation and hardware implementation of incremental conductance MPPT with direct control method using Cuk converter, IEEE Trans. Ind. Electron. vol.58, (2011), pp. 11541161.

[10] T. Esram, P.L Chapman, "Comparison of photovoltaic array maximum power point tracking techniques", IEEE Trans. Energy Convers. vol.22, (2007), pp. 439-449.

[11] M. S. Ismail, M. Moghavvemi and I.M.T Mahilia "Characterization of PV panel and global optimization of its model parameters using genetic algorithm”, Energy Convers. Manage. vol. 73, (2013), pp. 10-25.

[12] M.A. Farahat, H.M.B. Metwally, A.A. Mohamed, "Optimal choice and design of different topologies of DC-DC converter used in PV systems at different climatic condition”. RenewEnergy. vol.43, (2012), pp. 393-402.

[13] A. J. Sabzali, E. H. Ismail , H. M. Behbehani, "High voltage step-up integrated double Boost-Sepic DC-DC converter for fuel-cell and photovoltaic applications", Proceedings of the 4th International Congress on Renewable Energy: Generation and Applications, Milwakee, USA, (2014) October 19-22.

[14] Z. Dongbing, "Designing a SEPIC converter", National Semiconductor (Texas Instrument), Application Note 1484, (2013).

[15] K.S. Tey, S. Mekhilef, "Modified incremental conductance MPPT algorithm to mitigate in accurate responses under fast-changing solar irradiation level", Solar Energy. vol.101, (2014), pp. 333-342.

[16] V. Salas, E. Olias, A. Barrado, A Lazaro. "Review of the maximum power point tracking algorithms for standalone photovoltaic systems”. Solar Energy Materials \& Solar Cells (2006);90:1555-1578. 


\section{Appendix:}

\section{Specifications of PV generator}

\begin{tabular}{lc}
\hline Electrical Data & Value \\
\hline Nominal output $\mathrm{P}_{\mathrm{mpp}}(\mathrm{W})$ & 60 \\
Nominal Voltage $\mathrm{V}_{\mathrm{mpp}}$ & 67 \\
Nominal current $\mathrm{I}_{\mathrm{mpp}}(\mathrm{A})$ & 0.9 \\
Open circuit voltage $\mathrm{V}_{\mathrm{oc}}(\mathrm{V})$ & 92 \\
Short circuit current $\mathrm{I}_{\mathrm{sc}}(\mathrm{A})$ & 1.19 \\
\hline
\end{tabular}

\section{Authors}

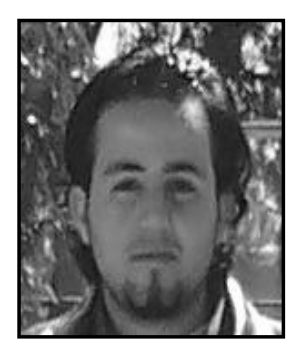

Hichem Othmani, was born in Tunisia. He received master degrees in electronics from the Faculty of Sciences of Tunis in 2012. Between 2013 and 2014, he occupies a temporary technologist position at Higher Institute of Technological Studies of Zhagwen (Tunisia). Actually, he is a $\mathrm{PhD}$ student in electronics in the Faculty of Sciences of Tunis. He works on Fuzzy logic control, Photovoltaic Systems, optimization of the law controls by intelligent technics and its implementation on a embedded design.

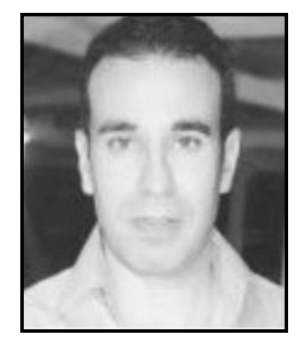

Dhafer Mezghani, was born in Tunisia. He received his Ph.D. in electrical engineering at the National School of Engineers of Tunis in 2009. He is an assistant-master at National School of Computer Science and it operates in the field of electronics and micro-electronics for embedded systems design (FPGA, microcontrollers) Also, its research affect the bond graph modeling, analyze and control of Renewable Energy systems (photovoltaic and wind) at the Faculty of Sciences of Tunis.

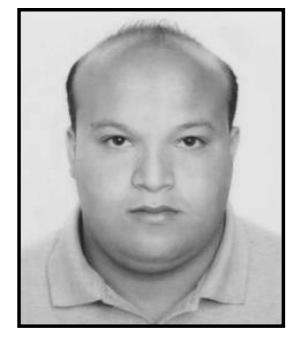

Ahmed Belaid, was born in Tunisia. He received master degrees in electronics in the Faculty of Sciences of Tunis in 2012. Between 2013 and 2015, he is a teacher at the school of Kalaat Landalos in Ariana-Tunisia. Actually, he is a PhD student in electronics in the Faculty of Sciences of Tunis, and he works on sliding mode control of a photovoltaic chain at the Faculty of Sciences of Tunis.

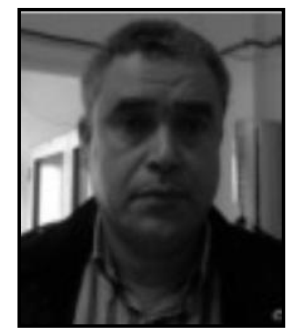

Abdelkader Mami, was born in Tunisia. He is a Professor in Faculty of Sciences of Tunis (FST). He received his Dissertation H.D.R (Enabling to Direct of Research) from the University of Lille (France) 2003, he is a member of Advise Scientific in Faculty of Science of Tunis (Tunisia). 